\title{
$\beta$-mercaptoethanol assists efficient construction of sperm bacterial artificial chromosome library
}

Kohei Fujikura, Masanori Abe and Reiko Kuroda

\section{Supplementary information}

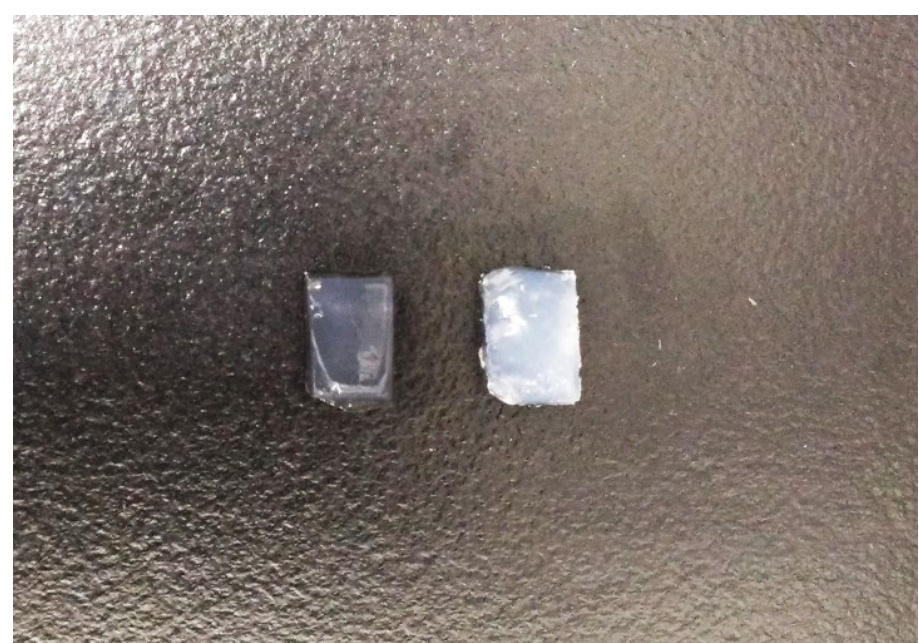

Figure S1. Agarose plugs from mouse sperm were treated with or without $\beta$-mercaptoethanol Sperm embedded in agarose plugs were treated with (left) or without (right) $\beta$-mercaptoethanol. Agarose plugs become clear after $\beta$-mercaptoethanol treatment. 